\title{
Aminopeptidase Activity of Leptospira Strains
}

\author{
By S. D. NEILL*, L. R. REID AND W. A. ELLIS \\ Veterinary Research Laboratories, Stoney Road, Stormont, Belfast BT4 3SD, U.K.
}

(Received 11 June 1982)

\begin{abstract}
A total of 15 cultures of Leptospira were examined for aminopeptidase activity using 22 aminoacyl- $\beta$-naphthylamide substrates. Activity was demonstrated in each of the cultures. Extracts from serovars of Leptospira interrogans preferentially hydrolysed the same range of substrates. The level of hydrolysis of the preferred substrates for the seven strains of $L$. interrogans was distinctively higher than that demonstrated for the six Leptospira biflexa strains. Extracts from cultures of Leptospira illini and Leptospira parva sp. nov. exhibited profiles different to those demonstrated for the other 13 leptospiral cultures examined.
\end{abstract}

\section{INTRODUCTION}

The leptospires are unusual amongst the aerobic prokaryotes, as little or no use has been made of biochemical characters in their taxonomy or identification. The genus Leptospira has traditionally been divided into two groups or complexes designated 'interrogans' and 'biflexa' (Turner, 1974). The complexes have now attained official acceptance as the distinct and genuine species Leptospira interrogans and Leptospira biflexa (Skerman et al., 1980), and contain the parasitic and saprophytic strains, respectively. Classification and subsequent identification of Leptospira is primarily based on serological analysis of cellular antigens and has resulted in subdivision into many serovars which, for practical purposes, are arranged into major serogroups of closely related serovars. Phenotypic characteristics have been examined to a limited degree and although of little taxonomic value they appear useful for distinguishing between pathogenic and saprophytic strains (Stalheim, 1973).

The possible use of enzymes in the classification of Leptospira was suggested following a study of a range of enzymes by electrophoresis (Green et al., 1967). The recognition of a naphthylamidase amongst these prompted further examination of leptospires for specific naphthylamidase activity (Burton et al., 1970). Aminopeptidases have been demonstrated in a variety of micro-organisms (Watson, 1976), and differences in substrate specificity have been used to distinguish between species of bacteria (Watson \& Perrine, 1975), fungi (Lee et al., 1975) and mycoplasmas (Neill \& Ball, 1980).

In this study a number of leptospiral serovars were examined for aminopeptidase activity using 22 aminoacyl- $\beta$-naphthylamide substrates and compared their substrate specificities.

\section{METHODS}

Organisms. Details of the 15 Leptospira strains employed in this study are presented in Table 1 . The cultures were maintained by weekly subculture in polysorbate-bovine serum albumin medium (Johnson \& Harris, 1967) containing $1 \%(\mathrm{v} / \mathrm{v})$ rabbit serum and $0 \cdot 15 \%(\mathrm{v} / \mathrm{v})$ purified agar (Baltimore Biological Laboratories). Rabbit serum used in the medium was a pool of sera from more than 10 rabbits serologically negative for Leptospira. The serum was inactivated at $56^{\circ} \mathrm{C}$ for $30 \mathrm{~min}$ and stored at $-20^{\circ} \mathrm{C}$ until required. The complete medium was stored at $4{ }^{\circ} \mathrm{C}$.

Preparation of cell extracts. Each strain was inoculated into $100 \mathrm{ml}$ volumes of liquid medium with or without serum. After incubation at $30^{\circ} \mathrm{C}$ for $7 \mathrm{~d}$ organisms were harvested by centrifugation at $10000 \mathrm{~g}$ for $1 \mathrm{~h}$. The resulting supernatants were used as a source of crude extracellular enzyme. The deposit was washed in 5-10 ml of $0 \cdot 1 \mathrm{M}$-Tris/ $\mathrm{HCl}$ buffer $\mathrm{pH} 8.0$, centrifuged as above and the washing was added to the original supernatant which was held at $-20^{\circ} \mathrm{C}$ until required. The final cell deposit was resuspended in $10 \mathrm{ml} 0 \cdot 1 \mathrm{M}$-Tris/ $\mathrm{HCl}$ buffer. Cell suspensions were ultrasonicated three times for periods of $45 \mathrm{~s}$ at $30 \mathrm{~s}$ intervals at maximum amplitude $(12 \mu \mathrm{m})$, using a disintegrator (MSE mk II). During sonication the sample container was packed in ice. The sonicate was 
Table 1. Organisms used

\begin{tabular}{|c|c|c|c|}
\hline Species & Serogroup & Serovar & Strain* \\
\hline L. interrogans & $\begin{array}{l}\text { Hebdomadis } \\
\text { Hebdomadis } \\
\text { Icterohaemorrhagiae } \\
\text { Canicola } \\
\text { Grippotyphosa } \\
\text { Pomona } \\
\text { Australis }\end{array}$ & $\begin{array}{l}\text { Hardjo } \\
\text { Mini } \\
\text { Icterohaemorrhagiae } \\
\text { Canicola } \\
\text { Grippotyphosa } \\
\text { Pomona } \\
\text { Lora }\end{array}$ & $\begin{array}{l}\text { Hardjoprajitno } \\
\text { Sari } \\
\text { RGA } \\
\text { Hond Utrect IV } \\
\text { CHI } \\
\text { Pomona } \\
\text { Lora }\end{array}$ \\
\hline L. biflexa & $\begin{array}{l}\text { Semaranga } \\
\text { Semaranga } \\
\text { Andamanda } \\
- \\
- \\
-\end{array}$ & $\begin{array}{l}\text { Semaranga } \\
\text { Patoc } \\
\text { Andamanda } \\
\qquad- \\
- \\
\text { Illini }\end{array}$ & $\begin{array}{l}\text { Veldrat S173 } \\
\text { Patoc } 1 \\
\text { CH11 } \\
762 \\
691 \\
796 \\
3055\end{array}$ \\
\hline L. parva sp. nov. & - & - & - \\
\hline
\end{tabular}

centrifuged for $1 \mathrm{~h}$ at $20000 \mathrm{~g}$. The resulting supernatant was assayed for enzyme activity, which was regarded as intracellular in origin. The extracts were stored at $-20^{\circ} \mathrm{C}$. Total protein in the extract was determined by the method of Hartree (1972).

Chemicals. The $\beta$-naphthylamide derivatives of alanine, isoleucine, serine, cystine and leucine (the latter as the hydrochloride) were supplied by Sigma; those of valine, phenylalanine, tyrosine, tryptophan, arginine, lysine (as carbonate), glycine and proline (as hydrobromides) and pyrrolidonyl- $\beta$-naphthylamide were obtained from I.C.N. Pharmaceuticals, Cleveland, Ohio, U.S.A.; the derivatives of histidine, 4-methoxyleucine, 4-hydroxyproline, 1aspartyl- $\beta$-naphthylamide and 5-glutamyl- $\beta$-naphthylamide were from Koch-Light; the derivatives of ornithine and glutamine were obtained from Cambridge Research Biochemicals, U.K. The $\beta$-naphthylamides were all derivatives of L-amino acids.

Enzyme assay. Aminopeptidase activity was measured by following the hydrolysis of aminoacyl- $\beta$ naphthylamides. Release of fluorescent $\beta$-naphthylamine was measured using a Perkin-Elmer spectrophotometer, model 204A (excitation $\lambda 337 \mathrm{~nm}$; emission $\lambda 408 \mathrm{~nm}$ ). Substrates $\left(10^{-4} \mathrm{M}\right)$ were dissolved in $0 \cdot 1 \mathrm{M}-\mathrm{Tris} / \mathrm{HCl}$ buffer, $\mathrm{pH} 8 \cdot 0$, and then dispensed in $2 \mathrm{ml}$ amounts into glass Bijou bottles, capped and sterilized by autoclaving for $10 \mathrm{~min}$ at $121^{\circ} \mathrm{C}$. L-Glutamyl- $\beta$-naphthylamide, which hydrolyses on autoclaving, was filter-sterilized prior to dispensing. Sterilized substrate solutions were stored at $4^{\circ} \mathrm{C}$ until required. The extract under test was added $(0.2 \mathrm{ml})$ to each of the buffered substrate solutions $(2 \mathrm{ml})$ in duplicate, the latter previously warmed to $37^{\circ} \mathrm{C}$. Incubation was continued for $4 \mathrm{~h}$, after which the mean fluorescence of duplicate reaction mixtures was determined. Substrate instability was corrected for by subtracting the mean fluorescence for the appropriate uninoculated buffered substrate solutions. The arbitrary fluorescence units were converted to $\mu$ mol $\beta$ naphthylamine released, using a linear calibration curve prepared with 5-100 $\mu$ mol $\beta$-naphthylamine. Aminopeptidase activity of cell extracts was recorded as $\mu \mathrm{mol} \beta$-naphthylamine formed (mg protein) ${ }^{-1}$.

\section{RESULTS AND DISCUSSION}

Aminopeptidase activity demonstrated using the crude bacterial extracellular preparations was minimal, as little or no increase in hydrolysis was observed relative to that obtained with the uninoculated culture medium. In preliminary experiments using uninoculated medium prepared without serum, the maximum hydrolysis demonstrated with any substrate was $<1.5 \mu \mathrm{mol} \beta$ naphthylamine released (mg protein) $)^{-1}$. Uninoculated medium containing serum, hydrolysed a larger range of substrates, due to serum aminopeptidase; however, the activity remained relatively low with all substrates, ranging from 0 to $14 \mu \mathrm{mol} \beta$-naphthylamine released (mg protein) $)^{-1}$.

Some hydrolytic activity was demonstrated with uninoculated medium treated similarly to the preparations of the intracellular extracts. This activity was again relatively low compared to the microbial intracellular activity and was only marginally affected by the incorporation of serum in the medium. Using extracts prepared from medium with and without serum, the hydrolysis observed ranged from 0 to $<22 \mu \mathrm{mol} \beta$-naphthylamine released (mg protein) ${ }^{-1}$. It was therefore considered that the hydrolytic activity of the medium constituents, extracted during the enzyme 
Table 2. Comparison of aminopeptidase activity of extracts of L. interrogans serovars grown in medium prepared with and without serum

Extracts were prepared from cultures grown in medium with and without $1 \%(\mathrm{v} / \mathrm{v})$ rabbit serum (see Methods). Enzyme activities were measured after $4 \mathrm{~h}$ incubation. Duplicate assays were carried out on two samples from each culture. The results are the mean activities of extracts from three individual cultures of each strain; the s.E.s are shown.

Aminopeptidase activity

[ $\mu \mathrm{mol} \beta$-naphthylamine released in $4 \mathrm{~h}(\mathrm{mg} \text { protein })^{-1}$ ]

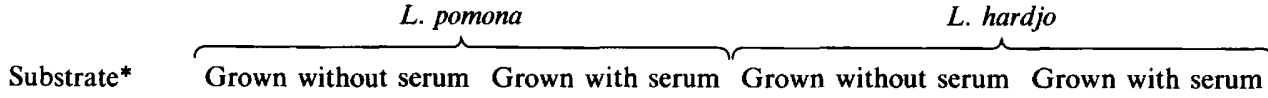

Ala-ONA
Val-ONA
Leu-ONA
Ile-ONA
Phe-ONA
(4-OMe)Leu-ONA
Asp-ONA
Glu-ONA
Lys-ONA
Arg-ONA
Ser-ONA
Tyr-ONA
Trp-ONA
Gly-ONA
Cys-ONA
Cys-ONA
Met-ONA
His-ONA
Pro-ONA
(4-OH)Pro-ONA
Pyr-ONA $\dagger$
Orn-ONA
Gln-ONA

$\begin{array}{rr}203.1 \pm & \pm 9.9 \\ 22.4 & \pm 7.5 \\ 246.8 \pm & \pm 1.7 \\ 26.8 \pm & 6.1 \\ 68.8 \pm & 11.2 \\ 149.2 \pm & 38.2 \\ 441.2 \pm & 89.0 \\ 31.0 \pm & 9.6 \\ 341.4 \pm & 103.8 \\ 223.3 \pm & 24.5 \\ 49.1 \pm & 6.7 \\ 78.9 \pm & 22.9 \\ 38.1 \pm & 10.9 \\ 39.2 \pm & 7.9 \\ 44.0 \pm & 5.6 \\ 80.9 \pm & 26.5 \\ 37.6 \pm & 8.0 \\ 23.7 \pm & 2.3 \\ 9.6 \pm & 1.9 \\ 6.0 \pm & 1.7 \\ 288.9 \pm & 77.7 \\ 475.1 \pm & 177.7\end{array}$

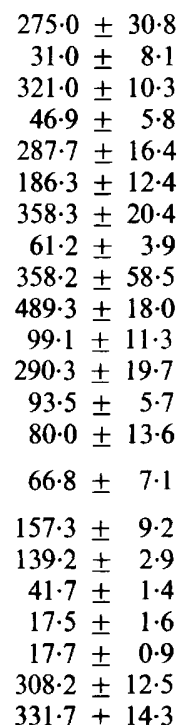

$135.9+38.7$

$2 \cdot 2 \pm 0.7$

$164 \cdot 9 \pm 30 \cdot 3$

$4 \cdot 1 \pm 1 \cdot 2$

$75 \cdot 4 \pm 21 \cdot 1$

$88 \cdot 3 \pm 18 \cdot 6$

$142 \cdot 6 \pm 54 \cdot 4$

$13 \cdot 0 \pm 2 \cdot 1$

$254 \cdot 1 \pm 43 \cdot 3$

$236 \cdot 5 \pm 46 \cdot 4$

$16.9 \pm 4 \cdot 0$

$62 \cdot 1 \pm 18 \cdot 1$

$17 \cdot 3 \pm 4 \cdot 6$

$26.6 \pm 12.5$

$168 \cdot 1 \pm 29 \cdot 9$

$36.0 \pm 9.2$

$232 \cdot 1 \pm 62 \cdot 7$

$40 \cdot 1 \pm 8 \cdot 4$

$86.7 \pm 22.5$

$138.6 \pm 33.2$

$383 \cdot 1 \pm 48 \cdot 0$

$61.6 \pm 7.6$

$399 \cdot 1 \pm 38 \cdot 3$

$140.4 \pm 49.6$

$56.4 \pm 11.2$

$98 \cdot 6 \pm 27 \cdot 7$

$70.6 \pm 14.5$

$43.8 \pm 3.0$

$31.4 \pm 6.3$

$43.9 \pm 18 \cdot 1$

$56.6 \pm 14.7$

$29.7 \pm 8.8$

$3.6 \pm 1.4$

$0.4 \pm 0.4$

$1.5 \pm 0.7$

$179 \cdot 1 \pm 20 \cdot 7$

$227.9 \pm 29.3$

$78.0 \pm 8.2$

$73.6 \pm 7 \cdot 1$

$29.7 \pm 4.7$

$3.9 \pm 1.5$

$10.3 \pm 4.0$

$107.7 \pm 19.2$

$375.7 \pm 55.4$

* -ONA, $\beta$-Naphthylamine derivative.

$\dagger$ Pyr-ONA, Pyrrolidonyl- $\beta$-naphthylamide.

preparation, contributed little to the activity of the leptospiral extracts. This was particularly evident for strains of $L$. interrogans. Although the contribution of serum aminopeptidase(s) to the activity of the leptospiral extracts was regarded as minimal, the latter activity was influenced by incorporation of serum into the medium. In an attempt to exclude this serum variable, eventual comparison of the strains under test was made using extracts of cultures grown in serum-free medium.

Intracellular aminopeptidase activity was demonstrated in each of the cultures examined. This hydrolytic activity was in general increased when rabbit serum was incorporated into the culture medium as illustrated by the two examples shown in Table 2 . In most instances, although there was a quantitative change in the level of hydrolysis of specific substrates, there was little evidence to suggest any major difference between the two types of media in the range of substrate preferentially hydrolysed.

The S.E.S of the mean aminopeptidase activity of intracellular enzyme preparations indicated relatively consistent hydrolysis of the substrates for each of the strains examined. The serovars of $L$. interrogans exhibited a definite and consistent range of substrates perferentially hydrolysed. These included the naphthylamide derivatives of alanine, arginine, aspartic acid, glutamine, leucine, lysine, methoxyleucine and ornithine (Table 3). Hydrolysis occurred with other substrates but to a lesser extent. A consistent pattern of preferred substrate hydrolysis was not so readily observed in the results from the saprophytic L. biflexa strains, however with the exception of 'semaramga' strains, these strains uniformly showed maximum hydrolysis of the 
Table 3. Comparison of the mean aminopeptidase activities of intracellular extracts from leptospiral strains of L. interrogans and L. biflexa

Extracts were prepared from cultures grown in medium without serum (see Methods). Enzyme activities were measured after $4 \mathrm{~h}$ incubation. Duplicate assays were carried out on two samples taken from each culture. The results are the mean activities of extracts of three individual cultures of each strain; the S.E.s are shown.

\begin{tabular}{lrr} 
& \multicolumn{2}{c}{$\begin{array}{c}\text { Aminopeptidase activity } \\
{[\mu \text { mol } \beta \text {-naphthylamine released in }} \\
4 \mathrm{~h}(\mathrm{mg} \text { protein) }\end{array}$} \\
\cline { 2 - 3 } \multicolumn{1}{c}{ Substrate* }
\end{tabular}

alanyl- $\beta$-naphthylamine substrate. Pathogenic leptospires in particular require nutritionally complex media for survival and propagation. The significance of many media constituents is, however, somewhat obscure, for example there have been contradictory reports about the necessity of amino acids in leptospiral media (Ono, 1938; Green, 1945; Johnson \& Rogers, 1964). Their exact role in leptospiral energy metabolism is unclear, but some amino acids are known to be incorporated into cellular components (Johnson \& Rogers, 1964). One possible explanation of the contradictory observations concerning amino acid requirements of leptospires might be the low cell permeability of free amino acids suggested by Johnson \& Rogers (1964). If small peptides were therefore preferentially transported, as has been observed in other bacteria (Wahren \& Holme, 1973), this could account for the intracellular exopeptidases demonstrated in this study. Thus amino acids, if required, could be made available intracellularly without addition of free amino acids to the media. The ability to consistently demonstrate intracellular aminopeptidase activity, apparently specific for a preferred range of substrates, suggests that such activity is possibly a part of the leptospiral cell metabolism.

Although some variation was exhibited in the level of hydrolysis, even for the preferred substrates of the $L$. interrogans strains, it was observed that the level of leucyl- $\beta$-naphthylamine hydrolysis was consistently higher for the parasitic strains than for the saprophytes. This is in agreement with the observations of Burton et al. (1970), but it is possibly unwise to place too much emphasis on the significance of leucine aminopeptidase per se, as the levels of hydrolysis of 
Table 4. Comparison of intracellular aminopeptidase activities of extracts of L. illini and $L$. parva sp. nov. using 22 aminoacyl- $\beta$-naphthylamide substrates

Extracts were prepared from cultures grown in medium without rabbit serum (see Methods). Enzyme activities were measured after $4 \mathrm{~h}$ incubation. Duplicate assays were carried out on two samples taken from each culture. The results are the mean activities of extracts prepared from three individual cultures of each strain; the S.E.S are shown.

\begin{tabular}{|c|c|c|}
\hline \multirow[b]{2}{*}{ Substrate* } & \multicolumn{2}{|c|}{$\begin{array}{c}\text { Aminopeptidase activity } \\
\text { [ } \mu \mathrm{mol} \beta \text {-naphthylamine released in } \\
\left.4 \mathrm{~h}(\mathrm{mg} \text { protein })^{-1}\right]\end{array}$} \\
\hline & L. illini & L. parva sp. nov. \\
\hline Ala-ONA & $95 \cdot 0 \pm 9.3$ & 0 \\
\hline Val-ONA & $7 \cdot 0 \pm 2 \cdot 2$ & $0.2 \pm 0.2$ \\
\hline Leu-ONA & $10.0 \pm 0.8$ & $0 \cdot 3 \pm 0.3$ \\
\hline Ile-ONA & $7.6 \pm 0.6$ & $0.7 \pm 0.3$ \\
\hline Phe-ONA & $10.4 \pm 0.3$ & $0 \pm 0$ \\
\hline (4-OMe)Leu-ONA & $3.7 \pm 0.2$ & $0.8 \pm 0.3$ \\
\hline Asp-ONA & $1.4 \pm 0.7$ & 0 \\
\hline Glu'-ONA & $4 \cdot 0 \pm 1 \cdot 1$ & $0.4 \pm 0.2$ \\
\hline Lys-ONA & $9.0 \pm 0.2$ & $0 \cdot 3 \pm 0.3$ \\
\hline Arg-ONA & $5.1 \pm 1.4$ & $0.7 \pm 0.1$ \\
\hline Ser-ONA & $27.0 \pm 6.5$ & $0.1 \pm 0.1$ \\
\hline Tyr-ONA & $12 \cdot 3 \pm 4 \cdot 1$ & $0.2 \pm 0.2$ \\
\hline Trp-ONA & $2.6 \pm 1.0$ & $0.3 \pm 0.3$ \\
\hline Gly-ONA & $187 \cdot 3 \pm 34 \cdot 7$ & $0.6 \pm 0.4$ \\
\hline Cys-ONA & $9 \cdot 0 \pm 4 \cdot 0$ & 0 \\
\hline Cys-ONA & & \\
\hline Met-ONA & $14.7 \pm 4.0$ & $3 \cdot 9 \pm 2 \cdot 1$ \\
\hline His-ONA & $26.1 \pm 7.9$ & $0 \cdot 3 \pm 0 \cdot 1$ \\
\hline Pro-ONA & $54.4 \pm 7.9$ & $0.3 \pm 0.3$ \\
\hline (4-OH)Pro-ONA & $107 \cdot 2 \pm 27 \cdot 2$ & $0.1 \pm 0.1$ \\
\hline Pyr-ONA† & $11.5 \pm 1.7$ & $0.2 \pm 0.1$ \\
\hline Orn-ONA & $0.2 \pm 0.4$ & $21.7 \pm 2.8$ \\
\hline GIn-ONA & $2.8 \pm 0.8$ & 0 \\
\hline
\end{tabular}

other substrates were also markedly higher for the parasitic compared to the saprophytic strains (Table 3). Burton et al. (1970) examined the aminopeptidase activities of leptospiral strains using only two substrates, and demonstrated a preferential hydrolysis by the saprophytic strains of the alanyl- over the leucyl- $\beta$-naphthylamide. The observation has been confirmed in this work (Table 3 ). Their observed preferential hydrolysis by the pathogenic strains of the leucylover alanyl- $\beta$-naphthylamide was also shown to be generally valid (Table 3 ), however it was only confirmed with five of the seven pathogenic strains tested and therefore may be invalid if a larger number of strains was examined.

An association between microbial aminopeptidase activity and pathogenicity has been suggested (Burton et al., 1970; Neill \& Ball, 1980; Watson \& Perrine, 1975). In this study differences in preferred substrate hydrolysis did exist between the potentially pathogenic $L$. interrogans strains and the saprophytic L. biflexa strains, and a most apparent quantitative difference in levels of hydrolysis was demonstrated for the two species (Table 3 ). It would unfortunately be inappropriate to extrapolate from these observations, as the $L$. interrogans strains employed had been subjected to prolonged passage in laboratory media and possibly might not reflect accurately the qualitative or quantitative substrate profile of fresh isolates. This aspect deserves further study.

Of the 22 substrates used in the assay, preferred hydrolysis by the extract from Leptospira illini was in the order glycyl-, hydroxyprolyl- and alanyl- $\beta$-naphthylamide (Table 4). The hydroxyproline- $\beta$-naphthylamide was not significantly hydrolysed by extracts from any of the 
other leptospiral strains tested. Similarly, with Leptospira parva sp. nov. extracts, only the ornithine substrate was hydrolysed to any extent. It is of interest to note that these two strains presented somewhat unique profiles of hydrolysis amongst the 15 cultures examined. HovindHougen (1979) distinguished $L$. illini from other leptospires on a morphological basis and suggested the creation of the new genus Leptonema. The results presented here using only one $L$. illini strain would not conflict with their findings. However, the creation of a new leptospiral species for the organism designated L. parva sp. nov. (Hovind-Hougen et al., 1981) appears inappropriate, as the results indicate no similarity with any of the leptospiral strains examined. The observed distinction of these two strains from Leptospira is supported to some extent by DNA base composition; leptospiral DNA ranges from $35-41 \mathrm{~mol} \% \mathrm{G}+\mathrm{C}$ whereas $L$. parva and $L$. illini have compositions of $47.4 \mathrm{~mol} . \% \mathrm{G}+\mathrm{C}$ and $51-53 \mathrm{~mol} . \% \mathrm{G}+\mathrm{C}$ respectively (Hovind-Hougen et al., 1981).

No attempt was made to establish whether the activity exhibited in any extract was from a single non-specific enzyme or from several enzymes specific for individual substrates. The intracellular hydrolytic activity exhibited by the cultures examined indicated greater homogeneity within $L$. interrogans than within L. biflexa and illustrated a uniqueness of activity for $L$. illini and $L$. parva sp. nov. It therefore appears that the aminopeptidase profile of Leptospira could serve as a taxonomic tool and might prove useful for interspecies and perhaps intraspecies differentiation.

\section{REFERENCES}

Burton, G., Blenden, D. C. \& Goldberg, H. S. (1970). Naphthylamidase activity of Leptospira. Applied Microbiology 19, 586-588.

GREEN, M. R. (1945). The influence of amino acids on the growth of Leptospira canicola. Journal of Bacteriology 50, 39-45.

Green, S. S., Goldberg, H. S. \& Blenden, D. C. (1967). Enzyme patterns in the study of Leptospira. Applied Microbiology 15, 1104-1113.

HaRTREe, E. F. (1972). Determination of protein: a modification of the Lowry method that gives a linear response. Analytical Biochemistry 48, 422-427.

Hovind-Hougen, K. (1979). Leptospiraceae, a new family to include Leptospira Noguchi 1917 and Leptonema gen. nov. International Journal of Systematic Bacteriology 29, 245-251.

Hovind-Hougen, K., Ellis, W. A. \& BIRCH-ANDERSON, A. (1981). Leptospira parva sp. nov.: some morphological and biological characters. Zentralblatt für Bakteriologie, Parasitenkunde, Infektionskrankheiten und Hygiene (Abteilung I) 250, 343354.

Johnson, R. C. \& HaRris, V. G. (1967). Differentiation of pathogenic and saprophytic leptospires. I. Growth at low temperatures. Journal of Bacteriology 94, 27-31.

Johnson, R. C. \& Rogers, P. (1964). Metabolism of Leptospirae. I. Utilisation of amino acids and purine and pyrimidine bases. Archives of Biochemistry and Biophysics 107, 459-470.

Lee, K. L., ReCa, M. E., Watson, R. R. \& CAMpbell,
C. C. (1975). Identification of yeast phase of pathogenic fungi by the specificity of their aminopeptidase(s). Sabouraudia 13, 132-141.

NeILl, S. D. \& Ball, H. J. (1980). Aminopeptidase activity of Acholeplasma laidlawii, Mycoplasma bovirhinis, Mycoplasma dispar and Mycoplasma bovis. Journal of General Microbiology 119, 103-107.

ONo, S. (1938). Experimentelle Studien über die Spirochaeta icterohaemorrhagiae. Fukuoka acta medica 31, 155-158.

Skerman, V. B. D., McGowan, V. \& Sneath, P. H. A. (1980). Approved Lists of Bacterial Names. Washington, D.C.: American Society for Microbiology.

Stalheim, O. H. V. (1973). Chemical aspects of leptospirosis. Critical Reviews in Microbiology 2, 423-456.

TURNER, L. H. (1974). Leptospira. In Bergey's Manual of Determinative Bacteriology, 8th edn, pp. 190-192. Edited by R. E. Buchanan \& N. E. Gibbons. Baltimore: Williams \& Wilkins.

Wahren, A. \& Holme, T. (1973). Amino acid and peptide requirement of Fusiformis necrophorus. Journal of Bacteriology 116, 279-284.

Watson, R. R. (1976). Substrate specificities of aminopeptidases: a specific method for microbial differentiation. Methods in Microbiology 9, 1-14.

Watson, R. R. \& Perrine, S. (1975). Differentiation of several Neisseria species of human origin by their aminopeptidase substrate specificities. Abstracts of the Annual Meeting of the American Society for Microbiology, p. 39. 